\title{
Review of the history to the present of Atlantic sturgeon (Acipenser oxyrinchus) in Latvian marine and inland waters with evidence from archeological sites
}

\author{
Santa Purvina, Maris Pliksh, Ruta Medne
}

Received - 22 May 2015/Accepted - 24 September 2017. Published online: 31 March 2019; $\odot$ Inland Fisheries Institute in Olsztyn, Poland Citation: Purvina S., Pliksh M., Medne R. 2019 - Review of the history to the present of Atlantic sturgeon (Acipenser oxyrinchus) in Latvian marine and inland waters with evidence from archeological sites - Fish. Aquat. Life 27: 3-14.

\begin{abstract}
Over the past few centuries, sturgeons have experienced decline and, in some cases, extinction worldwide caused primarily by habitat loss stemming from human activities and overfishing. The vulnerability of sturgeons to climate change and anthropogenic impacts is associated with their life characteristics, e.g., long life span, slow growth, late maturation, and specific spawning habitat requirements. Acipenser oxyrinchus Mitchill inhabited the Baltic Sea from at least 5,000 years before the Common Era until the twentieth century. It spawned in Latvia rivers and migrations during the Bronze Age and Middle Ages were intense. As early as the eighteenth century, single sturgeon catches are found in records, and these were identified as extraordinary cases. Although fisheries in river spawning grounds can lead to stock decline, the decline of sturgeons in Latvian waters was more likely determined by climate change, probably cooling or the so-called Little Ice Age that lasted from 1550 until 1850. Our records suggest that at the end of seventeenth and the beginning of the eighteenth centuries, the Northern border of sturgeon distribution moved southward. Latvian marine and freshwaters become the northern border of the species' areal, while it was still fished in Poland and Germany before its complete extinction in the twentieth century.
\end{abstract}

\footnotetext{
Santa Purvina [ڤ], Maris Pliksh, Ruta Medne

Fish Resources Research Department,

Institute of Food Safety, Animal Health and Environment "BIOR”,

8 Daugavgrivas St., Riga LV-1048, Latvia

e-mail: Santa.Purvina@bior.lv
}

Keywords: Acipenser oxyrinchus, archaeology, occurrence, distribution, Daugava River, Baltic Sea

\section{Introduction}

Sturgeons (Acipenseridae) are one of the oldest Osteichthyes fish families, and they are considered to be a living fossil (Gardiner 1984). The earliest data on North American sturgeons remains comes from the Late Cretaceous (Santonian to Campanian Milk River Formation) (Hilton and Grande 2006), while the first confidently identified remains of sturgeons from Europe or Asia are from the Lower Eocene in England and France (Kovalchuk and Hilton 2017). They have not undergone large morphological changes. Sturgeons have conserved morphology, respectable evolutionary age, unique benthic specializations, multiple levels of ploidy, and various basic diadromous life history; they are also of great public interest because of their near extinction and critically endangered status (Choudhury and Dick 1998, Birstein and Bemis 1997, Peng et al. 2007).

Sturgeons are a small group of fishes, and only one species is native to the Baltic Sea-the Atlantic sturgeon (Acipenser oxyrinchus Mitchill). The 
formation of the sturgeon sea lineage occurred more than 171 million years ago when the Tethys Ocean split and the Atlantic and Pacific oceans formed (Smith et al. 1994). The split between the North American A. oxyrinchus and the European Acipenser sturio L. occurred more than 121 million years ago (Smith et al. 1994, Peng et al. 2007). The Atlantic sturgeon further separated into two subspecies: the Atlantic sturgeon (North American East Coast populations), A. oxyrinchus oxyrinchus, and the Gulf sturgeon, A. oxyrinchus desotoi. Furthermore, A. o. oxyrinchus preceded a trans-Atlantic colonization of Baltic waters by founding a self-reproducing population. Acipenser sturio and A. oxyrinchus were finally separated about 58 million years ago; thus, this occurred somewhat earlier than the final closure of the Tethys Sea (Peng et al. 2007). Both species exhibit strong homing behavior and usually return to their natal rivers for spawning; however, straying is also recorded, and they can colonize other river systems (Wirgin et al. 2007).

Until 2002, it was believed widely that the Baltic Sea had been inhabited by $A$. sturio, which had, at the time, been reduced to a relict population in the Gironde River (Kottelat and Freyhof 2007), whereas the distribution of the American Atlantic sturgeon ( $A$. oxyrinchus) in the western Atlantic stretches along North America from southern Labrador to northern Florida (Vecsei and Peterson 2000).

Genetic studies first concluded that the Baltic Sea was colonized by $A$. o. oxyrinchus during the Middle Ages (approximately 1,200 years ago) and that it replaced the native $A$. sturio before it became extinct because of anthropogenic impacts (Ludwig et al. 2002). Later studies revealed that $A$. oxyrinchus introgressed into rather than replaced the $A$. sturio population in the Baltic since the genetic mosaic pattern of the Baltic sturgeon population ("oxyrinchus" mtDNA, "sturio" and "oxyrinchus" MHC alleles) possibly stemmed from sex-biased introgression (Tiedemann et al. 2007). According Popović et al. (2014) the high level of introgression of the Baltic population by $A$. sturio alleles and the lack of first-generation hybrids in the Baltic Sea suggests that the Baltic was already initially colonized by A. $o$. oxyrinchus and was already hybridized with $A$. sturio. This indicates the much earlier origin of the $A$. oxyrinchus population in the Baltic Sea from approximately 4,000 to 5,000 years ago (Popović et al. 2014). In 2002, mitochondrial DNA haplotype analyses revealed that Baltic sturgeon had a closer affinity with $A$. oxyrinchus than with $A$. sturio (Ludwig at al. 2002). On 2014 was concluded that the absence of specimens in the Baltic that could be assigned to pure $A$. sturio indicated that this species has never occurred in the Baltic as a sustainable population (Popović et al. 2014). It was A. o. oxyrinchus which initially entered Baltic and founded an independent population (Chassaing et al. 2013). The conclusion drawn from the preceding information is that the Baltic Sea all records of sturgeon related to our review, starting from archaeological findings to catch records from the nineteenth century, refer to $A$. o. oxyrinchus, and not to $A$. sturio, as was previously believed.

The Atlantic sturgeon was one of the largest fishes occurring in the Baltic Sea drainage basin until the end of the twentieth century, and it ascended the large rivers of the Baltic Sea from the Oder to the Neva to spawn. The status of the extinct Atlantic sturgeon population is not fully known. Since sturgeons exhibit homing behavior, historically several local stocks or populations could have been associated with certain river basins. In the nineteenth and twentieth centuries sturgeon was reported in the following river basins in the Baltic region: the Neva River, including landlocked populations in Lake Ladoga; the Neman River; the Vistula River; and the Oder River (Berg 1948, Hočlík et al. 1989). The last sturgeon catch in Poland was recorded in 1965 in the lower reaches of the Vistula River (Grabda 1968) and in Latvia in 1963-64 (Plikss and Aleksejevs 1998), while the last endemic sturgeon was caught in the Baltic Sea on the coast of Estonia near Muhu Island in 1996 (Paaver 1999).

The current status of the Atlantic sturgeon is considered to be near threatened (NT) globally, but there are certain differences between the western Atlantic and the Baltic populations. In 2012, four of the five distinct population segments were designated as endangered under the United State Endangered 
Species Act, but the Gulf of Maine segment was designated as threatened (Hilton et al. 2016), whereas, the wild Atlantic sturgeon is extinct in the Baltic Sea. The widely-held opinion that the Baltic Sea was populated historically by $A$. sturio was disproved only recently, and A. o. oxyrinchus was not included in the European Red List of Freshwater Fishes (Kottelat and Freyhof 2007, Freyhof and Brooks 2011). It is also not listed in the Habitats Directive, but it is included in Annexes II and V, because A. o. oxyrinchus had not been identified as a separate species in the Baltic region when the Directive was compiled. Similarly, the Baltic Atlantic sturgeon population is listed in Appendix III of the Bern Convention.

Nearly twenty years ago, a program to re-establish the native Baltic $A$. o. oxyrinchus was initiated in Germany and Poland, with releases of stocking material in Latvia, Lithuania and Estonia. $A$. oxyrinchus juveniles from the population inhabiting the St. John River (Canada) were first released in the Peene River (Germany) and Drwęca River (Poland) in 2006 (Fredrich et al. 2008, Kolman et al. 2008, 2011) and later were released into the Nemunas River (Lithuania). The first $A$. oxyrinchus juveniles were released in Latvia into the Daugava River in 2013 (Purvina and Medne 2018). Stocking efforts continue in the Baltic Sea and have recently focused on the southern rivers of the Baltic Sea including the Oder, Vistula, Pregola, Nemunas, Daugava, and Narva, and more than three million fish of various sizes had been released there up to 2018 (Fredrich et al. 2018).

The goal of this paper is to review all available information on the occurrence of Atlantic sturgeon in Latvian marine and inland waters to evaluate its distribution range and possible population decreases. The main information about the historical ichthyofauna of Latvia from the Mesolithic Period until the Iron Age comes from the work of ichthyologist Janis Sloka (1920-1997), whose studies were based on fish bone material collected at archaeological digs of human settlements located near inland lakes and rivers, in ancient castle mounds, and in towns (Sloka 1975, 1970, 1977, 1979, 1984, 1985, 1986a, 1986b, 1988a, 1988b, 2000). Sloka's osteometric research was based on the collection he assembled of Latvian fish skeletons that permitted determining fish species and sizes (Gaumiga and Seisuma 2002). Altogether, Sloka determined 25 fish species in more than 30 ancient settlements. The most detailed information on abundant sturgeon remains and ichthyofauna structure comes from the Daugava River basin, where fish species finds were studied in 24 ancient settlements. It should be noted that in these zooarcheological studies, Sloka identified all sturgeon remains as $A$. sturio, because $A$. $o$. oxyrinchus was identified later from $A$. sturio. Archeological findings are listed in this work according to periods dated by the authors, the territory of Latvia, and the history of the Baltic region formed after the Baltic Ice Lake melted in the post-Holocene period 12,000 BC.

Our research hypothesis was that the analysis of archeological sites and fish catch records can outline the geographical distribution of sturgeon populations and permit speculation as to the reason for its decrease in the Baltic area. This overview of the Atlantic sturgeon records in Latvian waters is also discussed in the light of new prospects and challenges for re-introducing this species into the studied area.

\section{Study site}

The Baltic Sea is one of the world's major brackish water basins that was formed after the last glacial period when ice cover melted more than 10,000 years ago. The territory of Latvia has a dense river network comprised of approximately 12,300 rivers, of which only 17 are longer than $100 \mathrm{~km}$. The largest Latvian river is the Daugava, the source of which is the Valdai Hills of Russia, and then it flows through Belarus. The Daugava flows through Latvia from the northeast and discharges into the Gulf of Riga, with a total length of 1,005 km, and an average water runoff of approximately $21 \mathrm{~km}^{3}$ annually. The other large rivers in Latvia are the Gauja (length $452 \mathrm{~km}$, runoff $2.2 \mathrm{~km}^{3}$ ), the Lielupe (length $119 \mathrm{~km}$, runoff 3.6 $\mathrm{km}^{3}$ ), the Venta (length $346 \mathrm{~km}$, runoff $2.9 \mathrm{~km}^{3}$ ), and 


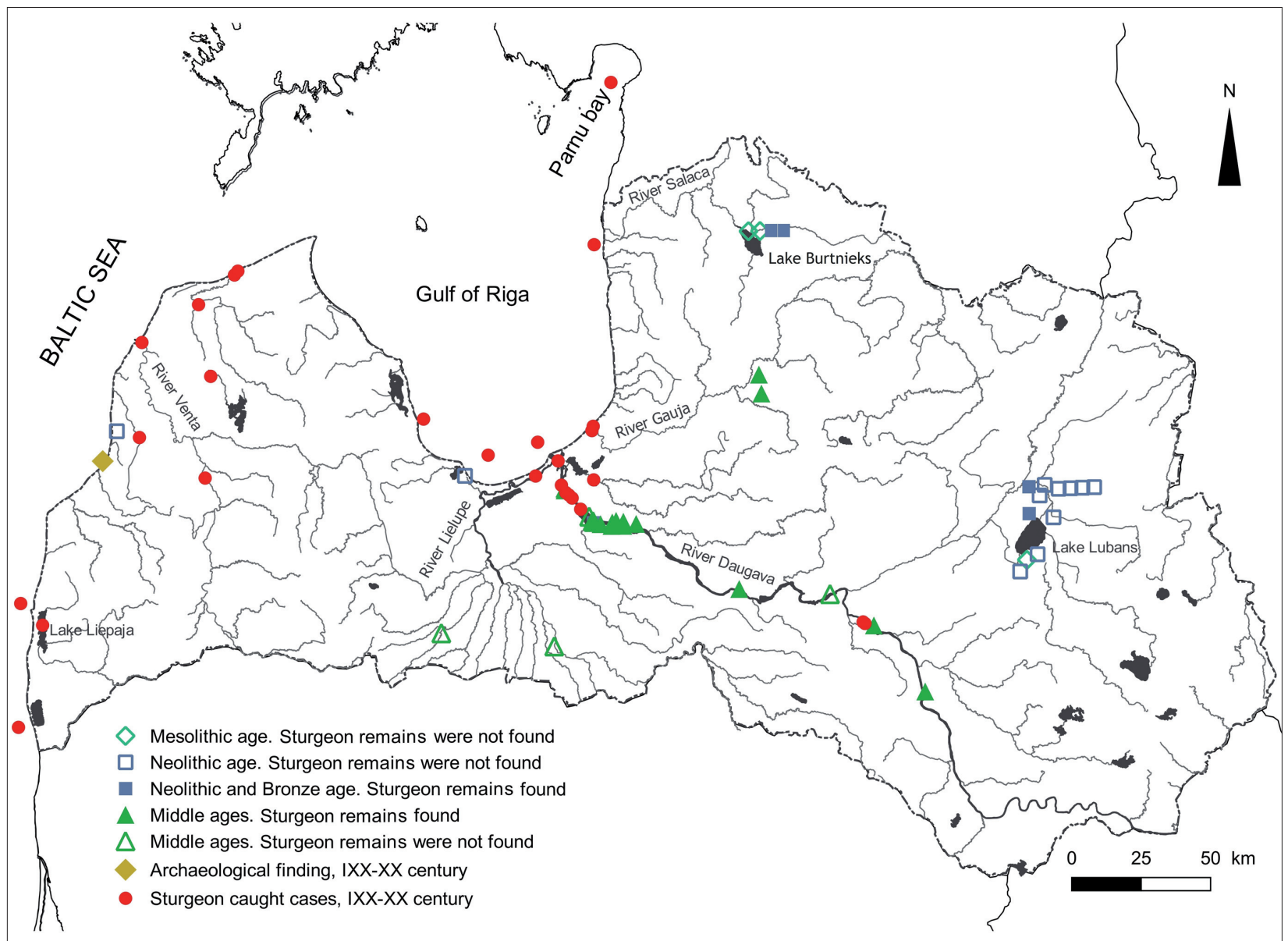

Figure 1. Sturgeon catch sites in Latvia from the Mesolithic Period to the present.

the Salaca (length $95 \mathrm{~km}$, runoff $0.95 \mathrm{~km}^{3}$ ). The Lielupe, Salaca, and Gauja rivers flow into the Gulf of Riga, but the Venta directly into the Baltic Sea. The Venta River has a natural barrier of a waterfall approximately $1.8-2.0 \mathrm{~m}$ high located $85 \mathrm{~km}$ upstream from its mouth.

The marine waters of the Latvian coastline can be separated into two ecological areas: the eastern Baltic proper and the Gulf of Riga. The average depth of the Gulf of Riga is two times less than that of the Baltic Sea. The low salinity of the water is because of the relative isolation of the gulf from the Baltic Sea and the rather high river discharge. The average annual freshwater inflow is $31 \mathrm{~km}^{3}$, with $86 \%$ of this flowing into the southern part of the gulf (Berzins 1995). The salinity of the gulf ranges from 0.5 to $2.9 \mathrm{psu}$ in spring in the surface water layers of the southern shallow zone to 7.5-7.7 psu in the bottom layers of the Irbe Sound in spring and summer (Berzins 1995). Salinity in the Baltic Sea proper is higher at 7.5-8.0 psu in the surface water layer and 10-13 psu in the bottom layers (Kullenberg 1981). The temperature regime in both areas fluctuates considerably seasonally, especially in the upper layer. During fall and early winter the homohaline surface layer becomes homothermal through a combination of thermohaline and mechanical wind-induced mixing. The spring and summer thermocline forms annually at depths between 15-20 m (Kullenberg 1981).

\section{Mesolithic Period (9000-5400 BC)}

The first information about the ichthyofauna of Latvia is based on material obtained from the ancient settlements of Sulagals, Osa, and Zvidze and the fisher settlement of Zvejnieki II of the Mesolithic 
Table 1

Findings of Acipenser oxyrinchus remains in archaeological excavations from the Stone Age, Bronze Age, and Neolithic Period

\begin{tabular}{|c|c|c|c|c|}
\hline Date & Site & Location & Notes & Information source \\
\hline $5090 \pm 55 \mathrm{BC}$ & $\begin{array}{l}\text { Zvejnieki Stone Age } \\
\text { cemetery Grave No.228 }\end{array}$ & $\begin{array}{l}\text { Lake Burtnieks at the } \\
\text { inflow site of the Ruja } \\
\text { River, Salaca River basin }\end{array}$ & $\begin{array}{l}\text { two human and one bird } \\
\text { figurine made from } \\
\text { sturgeon scutes }\end{array}$ & $\begin{array}{l}\text { Zagorskis } 1987 \\
\text { Meadows et al. } 2016\end{array}$ \\
\hline $4100-2900 \mathrm{BC}$ & Fisher settlement I & $\begin{array}{l}\text { Lake Burtnieks, Salaca } \\
\text { River basin }\end{array}$ & $\begin{array}{l}\text { one sturgeon scute } \\
\text { fragment }\end{array}$ & $\begin{array}{l}\text { Found in archaeological } \\
\text { excavations (2015) led } \\
\text { by Marcis Kalninsh and } \\
\text { Ilga Zagorska }\end{array}$ \\
\hline $4000-2500 \mathrm{BC}$ & Settlement Zvidze & $\begin{array}{l}\text { Lake Zvidze, Daugava } \\
\text { River basin }\end{array}$ & $\begin{array}{l}\text { 3,873 fish bones, } 8 \text { fish } \\
\text { species, several large } \\
\text { sturgeon specimen scute } \\
\text { fragments }\end{array}$ & Sloka 1986a \\
\hline $2000-1500 \mathrm{BC}$ & Abora Settlement & $\begin{array}{l}\text { Abora and Aiviekste } \\
\text { rivers, Daugava River } \\
\text { basin }\end{array}$ & $\begin{array}{l}\text { 2,084 fish bones, } 14 \text { fish } \\
\text { species, one sturgeon } \\
\text { scute }\end{array}$ & Sloka 1975 \\
\hline
\end{tabular}

Period. The settlements of Sulagals, Osa, and Zvidze are located near Lake Lubans, Latvia's largest, but settlement of Zvejnieki II is located near Lake Burtnieks (Fig. 1). Lake Lubans is connected with the Baltic Sea by the Aiviekste and Daugava rivers, while Lake Burtnieks is connected to the sea by the Salaca River. No remains of Atlantic sturgeon, A. o. oxyrinchus, were found at the Mesolithic settlements located near these lakes; nevertheless, the earliest remains of the diadromous fish species of salmon, Salmo salar L. and eel, Anguilla anguilla (L.) were identified in the fisher settlement of Zvejnieki II, which was populated from 8000-5400 BC. This suggests that these species migrated to this area either by inland waterways or were traded (Sloka 1985, Loze 2001, 2015). The dominant species in fisher catches was pike, Esox lucius L., and several specimens reached as much as $130 \mathrm{~cm}$ in length and $20 \mathrm{~kg}$ in weight, while the largest catfish, Siluris glanis L., found was $225 \mathrm{~cm}$ long (Loze 2015).

\section{Neolithic period (5400-1800 BC)}

The earliest known sturgeon remains were found at the Stone Age cemetery of Zvejnieki by Zagorskis (1987). One bird and two human head figurines made from sturgeon scutes were discovered in male grave No. 228 (Fig. 1, Table 1). The exact dating of the bird figurine is $5090 \pm 55 \mathrm{BC}$ (Meadows et al. 2016). The Zvejnieki II settlement is near Lake Burtnieks in northeastern Latvia. Dating from 8000-3000 BC, this is the largest Stone Age cemetery in the eastern Baltic where 330 inhumations have been excavated (Zagorskis 1987, 2004). The archaeological material from this site is from the Mesolithic and Neolithic periods. The figurine suggests that at the beginning of Neolithic period sturgeon either ascended the Salaca River to Lake Burtnieks, or was brought there by traders. The second piece of evidence is the sturgeon scute fragment found in vicinity of Lake Burtnieks from the fisher settlement of Zvejnieki I in archaeological excavations led by Marcis Kalninsh and Ilga Zagorska. This finding is dated 4100-2900 BC (Fig. 1, M. Kalninsh pers. comm.).

Almost all the fish remains found near Lake Lubans were of the freshwater species pike, roach, tench, wells catfish, pikeperch, and perch, and the highest number were of pike (93.75\%), but several large sturgeon scute fragments were also found that were dated to 4000-2500 BC (Zvidze settlement, Sloka 1986a). Another scute fragment from the Neolithic period was found at the Abora settlement 


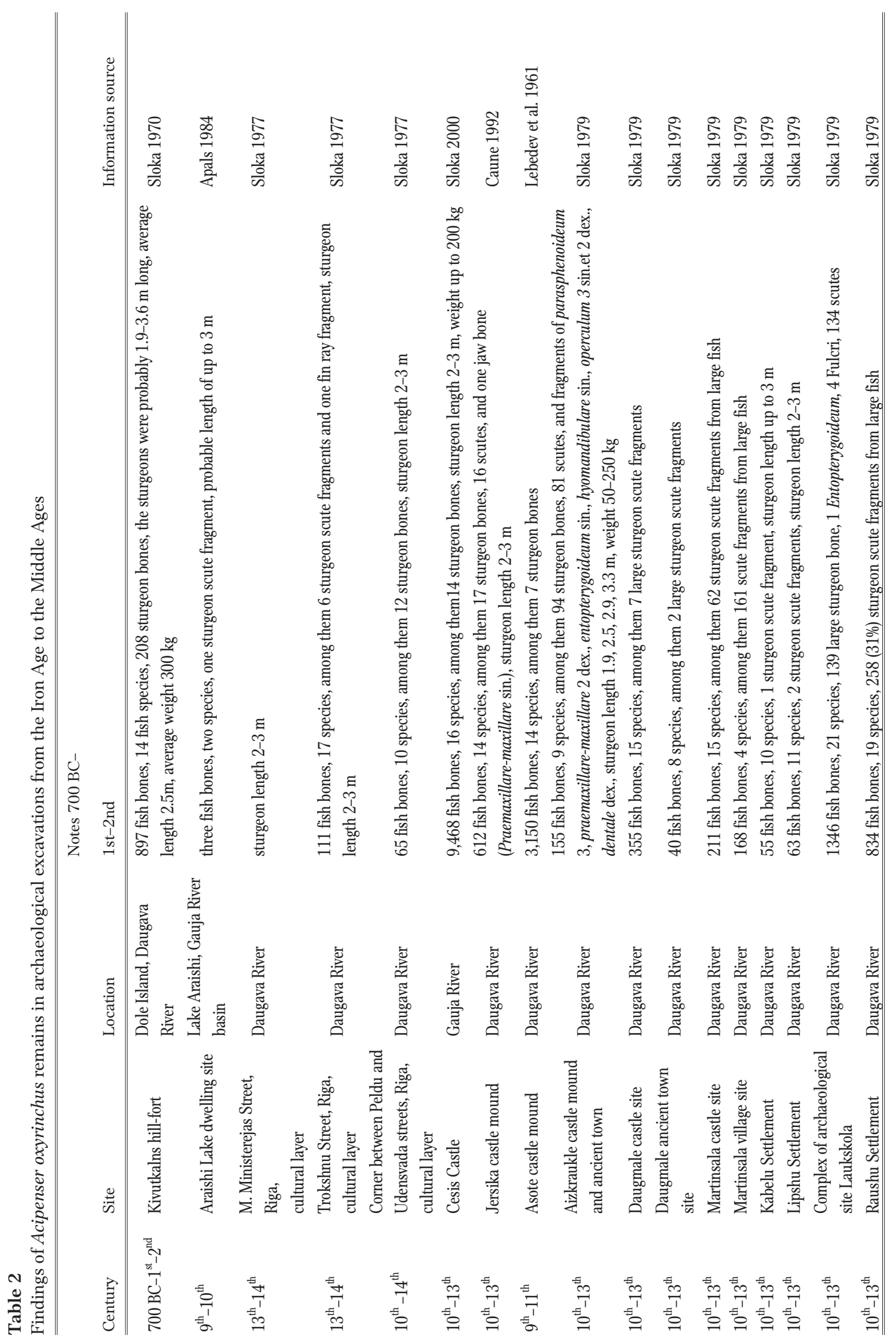


(2000-1500 BC) among 2,084 remains of 14 fish species (Sloka 1975).

\section{Bronze Age (1800-500 BC)}

The first convincing evidence of sturgeon fishing in Latvia comes from the Daugava Kivutkalns hill-fort on Dole Island (Fig. 1), which dates to 700 BC-200 CE. During this time, inhabitants of the Daugava region caught sturgeon that concentrated in shallower areas during spawning. Obviously, it was relatively easy to fish spawning sturgeon (Caune 1992). Sturgeon bones were found in all nine deposit layers, which suggests that sturgeon was a common, frequently caught species throughout the existence of the Kivutkalns hill-fort. The size of the sturgeon bones discovered in excavations indicated that the length of the specimens caught ranged from 192 to $360 \mathrm{~cm}$ at an average length of $251 \mathrm{~cm}$ and a maximum weight of $300 \mathrm{~kg}$. Large fish specimens were found almost exclusively in Kivutkalns. Sturgeon and pike were hunted with spears and arrows, while other large fish species were caught with large hooks. In total, 897 fish bones were found and 14 fish species were identified in Kivutkalns. Of all the identified fish remains, 23\% were of sturgeon; 39\% of pikeperch, Sander lucioperca (L.); 17\% of bream, Abramis brama (L.); 9.7\% of pike; 3\% of perch, Perca fluviatilis L.; $2.7 \%$ of zope, Ballerus ballerus (L.); and $1.8 \%$ of catfish. Additionally, remains were also identified of roach, Rutilus rutilus (L.); chub, Squalius cephalus (L.); ide, Leuciscus idus (L.); rudd, Scardinius erythrophthalmus (L.); silver bream, Blicca bjoerkna (L.); and vimba, Vimba vimba (L.) (Sloka 1970).

\section{Late Iron Age and early Middle Ages (800-1400)}

The most numerous sturgeon remain findings come from areas near the Daugava River, particularly from the Jersika, Asote, Daugmale, and Aizkraukle castle mounds, the Kabelu, Lipsu, and Rausu settlements, and from ancient Riga, Martinsala Castle, and village sites inhabited between the tenth and thirteenth centuries (Fig. 1). The percentage of sturgeon remains in settlements constitute from $2-95 \%$ of the total number of fish remains. Salmon bones were also found in all Daugava River basin settlements; however, in this period, the higher sturgeon bone share indicates that in some settlements sturgeon was caught much more commonly than was salmon. For instance, in the village of Martinsala, sturgeon bones in site deposits account for as much as $95 \%$, while salmon bones account for just 3\% and other species for 2\% (Sloka 1979, Caune 1992).

The abundance of sturgeon remains in all the settlements on the banks of the Daugava River is evidence that sturgeon was an important target species for fishers during the medieval period (Fig. 1, Table $2)$. However, while genetic analyses of sturgeon remains are lacking, the alveolar sculpting of the scutes found in medieval Riga (Caune 1992) indicates that they belong to $A$. oxyrinchus, not to $A$. sturio, as was previously thought (Ludwig and Gessner 2007).

In the Gauja River basin, sturgeon remains were found in the stone castle of Cesis (1300-1800 AD; Sloka 2000) and the Lake Araishi dwelling site (900-1000; Apals 1984), the approximate length of the individuals caught exceeded $3 \mathrm{~m}$. Additionally, significant quantities of cod, Gadus morhua L., and flounder, Platichthys flesus (L.), (15.05 and 0.04\% of the total fish bone material, respectively) remains were found at the castle of Cesis. Since these are marine species, they could only have reached this area through trade. Therefore, we can neither confirm nor deny whether sturgeon entered the Gauja River basin for spawning or through trade (Sloka 2000).

Sturgeon bones were not found at archaeological excavations in the Lielupe River basin, particularly not at the Mezotne hill-fort, located directly on the banks of the Lielupe River, or at the Tervete hill-fort, located on the Tervete River (Sloka 1986b). In the twelfth and thirteenth centuries, sturgeon was one of the most frequently mentioned fish species in Western European written documents. This fish was a valuable gift presented by envoys during official ceremonies (Ludwig and Gessner 2007), and during the thirteenth and fourteenth centuries, sturgeon was 
also consumed commonly in Livonian Riga. This is confirmed by archaeological materials collected from excavations of deposits of several streets that were investigated (Sloka 1977, Caune 1992).

\section{Early Modern Period (1500-1750)}

While no zooarcheological information is available from the early modern period, certain tax payment information is available from annals and chronicles. Riga rural county chancellery holding payments and notes made in the sixteenth and seventeenth centuries mention eight fish species-salmon, herring (Clupea harengus L.), smelt (Osmerus eperlanus (L.)), pike, bream, ide, eel, and sturgeon; however, detailed descriptions and rules are set out only for salmon fishing. For example, in 1659, 12 fisher groups fished in the Riga county of the Daugava River rural district. All the groups together had to pay 132 salmon to the city council as duty, and 85 salmon had to be sent to city council lords and masters. This is followed by a notice, that a fish levy of three salmon could be replaced by two sturgeon, which suggests that in the seventeenth century, sturgeon was less common than salmon (Caune 1992).

\section{Mid-Modern Period (1750-1914)}

Fischer (1791) described all the main fish species inhabiting the water bodies of Kurland in Livonia. The author wrote that sturgeon measuring from 1.7-3.2 $m$ in length were caught in Pärnu Bay, the Daugava River, and Lake Jugla (Fischer 1791). This permits postulating that as early as the eighteenth century sturgeon was rare and was not fished commercially (Fig. 1, Table 3). In Natural History of Livonia of 1858, Kawal wrote that sturgeon rarely entered the Gauja, Daugava, and Lielupe rivers from the Baltic Sea, and he also lists five separate sturgeon catches in the Baltic Sea at Liepaja and Rucava and in the Irbe, Venta, and Daugava rivers. Similarly, in 1893, Sapunow (cit. by Auzinsch 1925) remarks that sturgeon was fished formerly on the Vidzeme coastline in the Gulf of Riga from the end of April to May when sea ice was breaking up. There are no official, nineteenth century records about commercial sturgeon fishing in Latvia, and there are about ten notices in the public literature regarding catches of individual specimens in the Daugava, Gauja, Irbe, Rinda, and Venta rivers and in the Gulf of Riga (Table 3). For example, in 1887, the newspaper Dienas Lapa (Daily Sheet) reported on a farmer who had caught a sturgeon measuring $2.4 \mathrm{~m}$ and weighing $136 \mathrm{~kg}$ in the Engure River between the lakes of Usma and Puze.

\section{Contemporary Period (1914 - present)}

At the early twentieth century, before the World War I (1914-1918), several sturgeons were caught in the Daugava River. In the early 1920s, a sensational report was published in the public press of the catch of a sturgeon nearly $2 \mathrm{~m}$ in length in the mouth of the Daugava River. Between World Wars I and II (1939-1945), three sturgeon specimens were caught in the Daugava River, Liepaja Lake, and the small Uzava River (Table 6). After World War II, two sturgeons were caught in the coastal areas of the Gulf of Riga.

\section{Summary}

There are no records of sturgeon from Mesolithic settlements. This is mainly related to the fact that archaeological investigations of human settlements from this era are located near inland marshes and lakes. No zooarcheological studies on Mesolithic settlements have been located near the largest rivers, which are the main migratory routes for anadromous and catadromous fish. Fish remains from inland human settlement located near lakes are mainly from freshwater species. Similarly, in the Neolithic period, we lack archeological information from the immediate vicinities of the main rivers of the Daugava, Gauja, Venta, and Salaca (Fig. 1). Basic information comes from settlements located near Lake Burtnieks (upper segment of the Salaca) and Lake Lubans (Daugava River catchment area), and several records 
Table 3

Acipenser oxyrinchus catches, archaeological findings, and other literature references in Latvia, recent time

\begin{tabular}{|c|c|c|c|c|}
\hline $\begin{array}{l}\text { Century / } \\
\text { Date }\end{array}$ & Site & Location & Notes & Information source \\
\hline $18^{\text {th }}$ & $\begin{array}{l}\text { Daugava River, Lake } \\
\text { Jugla, Gulf of Parnu }\end{array}$ & $\begin{array}{l}\text { Separate known } \\
\text { catches }\end{array}$ & Sturgeon length $1.7-3.2 \mathrm{~m}$ & Fisher 1791 \\
\hline $19^{\text {th }}-20^{\text {th }}$ & Jurkalne & Baltic Sea shore & 44 sturgeon scutes and other bone remains & $\begin{array}{l}\text { Accidental findings in upper horizons during } \\
\text { control excavations of the Darvdegi ancient } \\
\text { burial site by archaeological expedition led by } \\
\text { Armands Vijups in } 2015 \text { (pers. comm.) }\end{array}$ \\
\hline 1806 & Venta River & Kuldiga Waterfall & 1 specimen caught & $\begin{array}{l}\text { Kawall } 1858 \text { (Cit. after Goldingen), Berg } \\
1911\end{array}$ \\
\hline 1821 & Daugava River & $\begin{array}{l}\text { Jekapils, } 150 \mathrm{~km} \\
\text { from Gulf of Riga }\end{array}$ & 1 specimen caught & $\begin{array}{l}\text { Kawall } 1858 \text { (cit. after Auzinisch 1925), Berg } \\
1911\end{array}$ \\
\hline 1821 & Daugava River & Jekabpils & 1 specimen caught & Kawall 1858, Berg 1911 \\
\hline 22.09 .1824 & Daugava River & near Riga & 1 specimen caught, length $1.8 \mathrm{~m}$ & $\begin{array}{l}\text { Kawall, } 1858 \text { (cit. after Auzinsch 1925), Berg } \\
1911\end{array}$ \\
\hline 1831 & Gulf of Riga & near Engure & 1 specimen caught, length exceeding $2.4 \mathrm{~m}$ & $\begin{array}{l}\text { Kawall } 1858 \text { (cit. after Auzinsch 1925), Berg } \\
1911\end{array}$ \\
\hline 1833 & Irbe River & & 1 specimen caught, length $1.7 \mathrm{~m}$ & Kawall 1858, Berg 1911 \\
\hline ca. 1833 & Rinda River & $\begin{array}{l}\text { Angerminde, Irbe } \\
\text { River basin }\end{array}$ & 1 specimen caught, length $1.7 \mathrm{~m}$ & Karali 1858 (cit. after Auzinsch, 1925) \\
\hline Prior to 1858 & $\begin{array}{l}\text { Gauja, Daugava, and } \\
\text { Lielupe rivers and } \\
\text { Baltic Sea at Liepaja }\end{array}$ & & rare catches & Kawall 1858, Berg 1911 \\
\hline Prior to 1858 & Baltic Sea at Rucava & & 1 specimen caught, length $1.8 \mathrm{~m}$ & Kawall 1858 \\
\hline 08 or 091887 & Engure River & & $\begin{array}{l}1 \text { specimen caught, length } 2.4 \mathrm{~m} \text {, weight } 136 \\
\mathrm{~kg}\end{array}$ & $\begin{array}{l}\text { reported in the newspaper Dienas lapa in } \\
1887\end{array}$ \\
\hline Early 20th & Daugava River & Daugava River & several specimens caught before World War I & Bērziņš 1934 \\
\hline 1922 or 1923 & Uzava River & near Terande & 1 specimen found on the river bank & Fisherman Kārkliņš (pers. comm.) \\
\hline 07.1923 & Daugava River & & $\begin{array}{l}1 \text { specimen caught, age } 20 \text { years, determined } \\
\text { by operculum, length } 1.5 \mathrm{~m} \text {, weight } 54 \mathrm{~kg}\end{array}$ & Auzinsch 1925 \\
\hline 1.09.1932 & Liepaja Lake & & $\begin{array}{l}1 \text { specimen caught, length } 0.7 \mathrm{~m} \text {, weight } 1.3 \\
\mathrm{~kg}\end{array}$ & Mannsfeld 1937 \\
\hline 8.08 .1935 & $\begin{array}{l}\text { Gulf of Riga near } \\
\text { Salacgriva }\end{array}$ & & 1 specimen caught, length $2 \mathrm{~m}$ & Mannsfeld 1937 \\
\hline 1963 or 1964 & $\begin{array}{l}\text { Gulf of Riga near } \\
\text { Jurmala }\end{array}$ & & last known catch of 1 specimen in Latvia & Vitins (pers. comm.) \\
\hline
\end{tabular}

of sturgeon remains suggest that this species was present in this region at that time. Therefore, we concluded that the sturgeon had inhabited and spawned in the inland waters of Latvia at least since the early Neolithic period.

Sturgeon was an important component of the ichthyofauna of the Bronze Age until the Medieval period, which is verified by archeological materials.
Sturgeon bone remains and records of catches are evidence that $A$. o. oxyrinchus occurred mainly in the largest rivers of the Daugava, Gauja, Salaca, and Venta. There is no evidence of sturgeon catches in the Lielupe River, however the species is mentioned in the first descriptions of the ichthyofauna (Table 3). Nevertheless, the richness of sturgeon remain findings in all settlements on the banks of the Daugava 
River from the early Iron Age until the early Medieval Age, separate findings and catch records from the Venta, Gauja, and Salaca river basins, and the absence of records from the Lielupe River basin can be explained by differences in the typology of these rivers. A significant part of the Lielupe catchment area is potamal with a current water flow velocity of less than $0.2 \mathrm{~m} \mathrm{~s}^{-1}$ and muddy sediment structure covered with organic detritus that is not appropriate for sturgeon spawn. Whereas in other rivers and the Daugava River, potamal stages alternated with rhithral streams with a current velocity in excess of $0.2 \mathrm{~m} \mathrm{~s}^{-1}$ and with carbonate rock, gravel, sand, and pebble sediments. Apparently since the spawning grounds in the Lielupe River were inadequate and inappropriate, the sturgeon preferred spawning in the Daugava and other rhithral rivers that offered appropriate hard bottom structures.

The decrease of $A$. oxyrinchus population size began as early as at the end of seventeenth century. Later, in the eighteenth, nineteenth, and twentieth centuries, sturgeon was no longer recorded in commercial fish catches, but there are records of single sturgeon catches that were reported as extraordinary cases. The pollution resulting from the development of manufacturing was not one of the main reasons for the decline of this species in Latvia. The industrial revolution in Latvia began in the late eighteenth and early nineteenth centuries, which was later than in Western Europe. It is also unlikely that ecosystem changes resulting from the deforestation of river basins could have caused the sturgeon population decrease, because, historically, Latvia was not densely populated. Additionally, damming rivers with hydroelectric dams that could have destroyed sturgeon spawning sites occurred later in the twentieth century. The most likely reason for the decline of sturgeon populations was global climate change. The Little Ice Age in Europe was from 1550 to 1850 (Niedźwiedź et al. 2015). Precise temperature measurements for the Baltic Sea region, including Latvia, began in the middle of the eighteenth century; nevertheless, earlier evidence of peculiarities in temperature regimes is seen in biological and physical variables that respond to climate change and can be found in nature. Scandinavian tree ring analyses indicate that there was a consecutive cold period from approximately the late sixteenth to the mid-eighteenth centuries that coincided with the Little Ice Age (Gouirand et al. 2008). Other indices, like ocean and lake sediments and ice cores, together with historical documentary material, also indicate that the northern hemisphere cooled during the sixteenth to the eighteenth centuries (National Research Council 2006). Winter severity from 1740 until 1880, assessed according to the timing of ice break-up time observed in Riga harbor (the southern part of the Gulf of Riga), was more frequently characterized as average to severe and average, coincided with average to severe winters (Jevrejeva 2001). We do not have precise, comparable historical information on air or water temperatures from this time, but, colder, longer winters and shorter cooler summers could affect $A$. oxyrinchus spawning and juvenile development. Apparently, in the late seventeenth and early eighteenth centuries, the northern border of sturgeon distribution shifted south, which meant that Latvia was the northern border of sturgeon population area of occurrence at the time.

Climate cooling in the nineteenth century was the opposite of recent warming. Nowadays, the trend is of increasing air temperature, sea level, and decreasing ice cover in the Baltic Sea (HELCOM 2007) and worldwide. From a climate point of view, we assume that presently conditions include longer summers, a warmer climate, and overwintering temperatures for better Atlantic sturgeon spawning outcomes and juvenile development. However, the success of reintroduction is highly dependent on other anthropogenic factors that are more pronounced in comparison with earlier historical periods.

Acknowledgments. The authors would like to express their gratitude to Prof. Andrejs Vasks and Dr. Gunita Zarina for arranging the historical chronology, Natalya Kondratyeva for her expert guidance in the literature search, and Janis Bajinskis for help in creating the graphic illustration of the data. Financial support was provided by the Ministry of Agriculture and Institute of 
Food Safety, Animal Health and Environment - "BIOR” under the contract "Fish Resource Regulation, Reproduction, and Research.”

Author contributions. S.P. searched and analyzed historical information, wrote the paper; M.P. contributed in the site and fish fauna description as well as in the statement of problem; R.M. contributed in the research.

\section{References}

Apals J. 1984 - About research of the lake castle Āraiši Jaunā Gaita 147: 23-30 (In Latvian).

Auzinsch W. 1925 - Sturgeon (Acipenser sturio L.) Zvejnieku Vēstnesis 4/5: 48 (In Latvian).

Berg L.S. 1911 - Fauna of Russia. Fishes - Vol. 1. Sankt-Petersburgh, 337 p. (in Russian).

Berg L.S. 1948 - Ryby presnikh vod SSSR i sopredelnykh stran - 4th Edition, Izdatelstvo Akademii Nauk SSSR, Moskva-Leningrad: 474 p. (in Russian).

Bērziņš B. 1934 - Rear fishes in the Gulf of Riga - Daba un zinātne 3: 81-84 (in Latvian).

Birstein V.J., Bemis W.E. 1997 - How many species are there within the genus Acipenser? - Environ. Biol. Fishes 48: 157-163.

Caune A. 1992 - ...Riga itself in the water - Zinātne, Rīga, 166 p. (in Latvian).

Choudhury A., Dick T.A. 1998 - The historical biogeography of sturgeons (Osteichthyes: Acipenseridae): a synthesis of phylogenetics, palaeontology and palaeogeography - J. Biogeogr. 25: 623-640.

Fischer J.B. 1791 - Versuch einer Naturgeschichte von Livland - Nicolovius, Konigsberg, 904 p. (in German).

Fredrich F., Kapusta A., Ebert M., Duda A., Gessner J. 2008 Migratory behavior of young sturgeon, Acipenser oxyrinchus Mitchill, in the Oder River drainage. Preliminary results of a radio telemetric study in the Drawa River, Poland - Arch. Pol. Fish. 16: 105-117.

Fredrich T., Gessner J., Reinartz R., Striebel-Greiter B. 2018 Pan-European Action Plan for Sturgeons - World Sturgeon Conservation Society and WWF, Council of Europe, Convention on the Conservation of European Wildlife and Natural Habitats, Standing Committee, 27-30 Nov., Strasbourg, $80 \mathrm{p}$.

Freyhof J., Brooks E. 2011 - European Red List of Freshwater Fishes - Publications Office of the European Union, Luxembourg, $88 \mathrm{p}$.

Gardiner B.G. 1984 - Sturgeons as living fossils - In: Living fossils (Eds) N. Edredge, S.M. Stanley, Springer Verlag, New York: 148-152.

Gaumiga R., Seisuma Z. 2000 - Janis Sloka (1920-1997), a well known Latvian ichthyologist - Proc. Latv. Acad. Sci. B, 56: 206-209.
Gouirand I., Linderholm H.W., Moberg A., Wohlfarth B. 2008 - On the spatiotemporal characteristics of Fennoscandian tree-ring based summer temperature reconstructions - Theor. Appl. Climatol. 91: 1-25.

Grabda E. 1968 - Sturgeon - disappearing fish - Ochr. Przyr. 33: 177-191 (in Polish).

HELCOM 2007 - Climate Change in the Baltic Sea - Helsinki Commission. Helsinki.

Hilton E.J., Grande L. 2006 - Review of the fossil record of sturgeons, family Acipensiredae (Actinopterygii: Acipenseriformes), from North America - J. Paleont. 80: 672-683.

Hilton E.J., Kynard B., Balazik M.T., Horodysky A.Z., Dillman C.B. 2016 - Review of the biology, fisheries, and conservation status of the Atlantic Sturgeon, Acipenser oxyrinchus oxyrinchus Mitchill, 1815 - J. Appl. Ichthyol. 32: 30-66.

Hočlík J., Kinzelbach R., Sokolov L.I., Vasil'ev P. 1989 Acipenser sturio Linnaeus, 1758. In: The freshwater fishes of Europe. General introduction to fishes, Acipenseriformes, Vol. 1, Part II. (Ed.) J. Holčík, AULA-Verlag, Wiesbaden: 367-394.

Jevrejeva 2001 - Severity of winter seasons in the northern Baltic Sea between 1529 and 1990: reconstruction and analysis - Clim. Res. 17:55-62.

Kawall H. 1858 - Fische in Kurland und an den Küsten der dasselbe begrenzenden Ostsee, mit Berücksichtigung von Livland - Das Inland Wochenschrift für Liv-, Est-und Kurland Curländische Geschichte, Geographie, Statistik und Litteratur 35: 561-568.

Kolman R., Kapusta A., Duda A., Wiszniewski G. 2011 Review of the current status of the Atlantic sturgeon Acipenser oxyrinchus oxyrinchus Mitchill 1815, in Poland: principles, previous experience, and results - J. Appl. Ichthyol. 27: 186-191.

Kolman R.V., Guschin A.V., Stratanovich D.B. 2008 - Present-day status of sturgeon stock and possibility for its restoring in the Baltic Sea - Rybnoe khozyaystvo 1: 78-81 (in Russian).

Kottelat M., Freyhof J. 2007 - Handbook of European Freshwater Fishes - Kottelat, Cornol, Switzerland and Fryhof, Berlin, Germany, 646 p.

Kovalchuk O., Hilton E.J. 2017 - Neogene and Pleistocene sturgeon (Acipenseriformes, Acipenseridae) remains from southeastern Europe - J. Vert. Paleontol. 37: e1362644.

Kullenberg G. 1981 - Physical oceanography - In: The Baltic Sea. (Ed.) A. Voipio, Elsevier Oceanography Series 30, Elsevier Scientific Publishing Company: 135-181.

Lebedev V.D., Markov K.P., Bahmetyeva T.L., Paskul M. 1961 - Fish and fishery of the inhabitants of the Asotskoye fortification (eleventh to thirteenth centuries) in the Daugava River - In: Fortification of Asote (Eds) 
E.D. Shnore, T.J. Zeyda, Academiya Nauk Latviyskoi SSR, Institut Istorii, Riga, 226-233 (in Russian).

Loze I. 2001 - Stone Age fishing in the largest Latvian lake basins - Latvijas Vēstures Institūta Žurnāls 4: 28-50 (in Latvian).

Loze I. 2015 - Lubana wetland habitation in the Stone Age Latv. Acad. of Sc., Rēzekne: 311 p. (in Latvian).

Ludwig A., Gessner A. 2007 - What makes the difference? Sea sturgeon on both sides of the Atlantic Ocean - In: Anadromous sturgeons: habitats, threats, and management (Eds) J. Munro, D. Hatin, J.E. Hightower, K. McKwon, K.J. Sulak, A.W. Kahnle, F. Caron, Am. Fish. Soc. Symp. 56: 285-300.

Ludwig A., Debus L., Lieckfeldt D., Wirgin I., Benecke N., Jenneckens I., Williot P., Waldman J., Pitra C. 2002 When the American sea sturgeon swam east - Nature 419: 447-448.

Mansfeld W. 1937 - Mitteilungen zur Fischfauna Lettlands II Korresp. Bl. Naturforscher Verein zu Riga LXII: 81-82.

Meadows J., Bērziņš V., Legzdiņa D., Lübke H., Schmölckea U., Zagorska I., Zaringa G. 2018 - Stone-age subsistence strategies at Lake Burtnieks, Latvia - J. Archaeol. Sci. 17: 992-1006.

National Research Council 2006 - Surface Temperature Reconstructions for the Last 2,000 Years - Washington DC, The National Academies Press, 160 p.

Paaver T. 1999 - Historic and recent records of native and exotic sturgeon species in Estonia - J. Appl. Ichthyol. 15: 129-132.

Peng Z., Ludwig A., Wang D., Diogo R., Wei Q., He S. 2007 Age and biogeography of major clades in sturgeons and paddlefishes (Pisces: Acipenseriformes) - Mol. Phylogenet. Evol. 42: 854-862.

Plikšs M., Aleksejevs E. 1998 - Fishes of Latvia - Gandrs, Rīga, 304 p. (In Latvian).

Popović D., Panagiotopoulou H., Baca M., Stefaniak K., Mackiewicz P., Makowiecki D., King T.L., Gruchota J., Weglenski P., Stankovic A. 2014 - The history of sturgeon in the Baltic Sea - J. Biogeogr. 41: 1590-1602.

Purvina S., Medne R. 2018 - Reintroduction of sturgeon Acipenser oxyrinchus in the Gulf of Riga, Central-Eastern Baltic Sea - Arch. Pol. Fish. 26: 39-46.

Sloka J. 1975 - Fish from the Stone Age settlements in the Lubana lowland - Izvestiya Academii Nauk Latviyskoi SSR 8: 65-73 (in Russian).

Sloka J. 1970 - Fish in Bronze Age in the ancient Daugava River - Latvijas PSR Zinātņu Akadēmijas Vēstis 11: 33-39 (in Latvian).
Sloka J. 1977 - Fish found in the thirteenth and fourteenth century cultural layers of Riga - Latvijas PSR Zinātņu Akadēmijas Vēstis 6: 100-107 (in Latvian).

Sloka J. 1979 - Fish in ancient tenth to fourteenth century settlements on the banks of the Daugava River - Latvijas PSR Zinātņu Akadēmijas Vēstis 9: 51-67 (in Latvian).

Sloka J. 1984 - Fish at Neolithic dwellings of the Sârnate wetland and Siliňupe settlement site - Latvijas PSR Zinātņu Akadēmijas Vēstis 6: 74-76 (in Latvian).

Sloka J. 1985 - Stone Age fish caught at settlement Zvejnieki II settlement (8000-6000 BC) - Latvijas PSR Zinātņu Akadēmijas Vēstis 7: 110-116 (in Latvian).

Sloka J. 1986a - Fish at the Mesolithic and Neolithic settlement of Zvidze (6000-3000 BC) - Latvijas PSR Zinātņu Akadēmijas Vēstis 9: 127-130 (in Latvian).

Sloka J. 1986b - Fish at the Tervete castle mound (1000-1300) and in the Mezotne castle mound (1100-1200) - Latvijas PSR Zinātņu Akadēmijas Vēstis 9: 131-135 (in Latvian).

Sloka J. 1988a - Fish at the Bauska castle mound in 1000 BC and in the sixteenth and seventeenth centuries - Latvijas PSR Zinātņu Akadēmijas Vēstis 6: 85-87 (in Latvian).

Sloka J. 1988 b - Fish catches at the Stone Age settlement of Osa in the Lubana lowland in 5000-4000 BC - Latvijas PSR Zinātņu Akadēmijas Vēstis 7: 89-91 (in Latvian).

Sloka J. 2000 - Fish bone findings in the ancient stone castle of Cesis (thirteenth to eighteenth centuries) - Latvijas vēstures institūta žurnāls 1: 126-130 (in Latvian).

Smith A.G., Smith D.G., Funnell B.M. 1994 - Atlas of Mesozoic and Cenozoic Coastlines - Cambridge University Press, Cambridge, 99 p.

Tiedemann R., Moll K., Paulus K.B., Scheer M., Williot P., Bartel R., Gessner J., Kirschbaum F. 2007 - Atlantic sturgeons (Acipenser sturio, Acipenser oxyrinchus): American females successful in Europe Naturwissenschaften 94: 213-217.

Vecsei P., Peterson D. 2000 - Threatened fishes of the world: Acipenser oxyrinchus Mitchill, 1815 (Acipenseridae) Environ. Biol. Fish. 59: 98.

Wirgin I., Grunwald C., Stabile J., Waldman J. 2007 Genetic evidence for relict Atlantic sturgeon stocks along the mid-Atlantic coast of the USA - N. Am. J. Fish. Manage. 27: 1214-1229.

Zagorskis F. 1987 - Zvejnieki Stone Age cemetery - Zinātne, Rìga, Latvia, 130 p. (in Latvian).

Zagorskis F. 2004 - Zvejnieki (Northern Latvia) Stone Age Cemetery - British Archeological reports 1292, Oxford, $147 \mathrm{p}$. 